\title{
Zagadnienia materiałowo-spawalnicze modernizowanego stalowego mostu kolejowego na linii nr 408
}

\author{
Materials and welding aspects \\ of bridge modernization of 408 railway
}

\section{Streszczenie}

Po pewnym okresie użytkowania obiektu budowlanego ulega zmianie jego zdolność do spełniania w pełnym zakresie funkcji projektowanych, a przede wszystkim jego trwałość technologiczna i użytkowa. Wyraźnie problem ten dotyczy kolejowych obiektów mostowych. Ponad 75\% tych konstrukcji liczy ponad 50 lat, z czego prawie 45\% jest eksploatowanych ponad 100 lat, czyli już przekroczyło zakładaną trwałość normatywną. Sukcesywnie obiekty te są wzmacniane i modernizowane. Wymaga to wcześniejszego poznania aktualnych cech materiałowo-wytrzymałościowych konstrukcji oraz spawalności stali.

$\mathrm{W}$ artykule zagadnienie to przedstawiono w związku z modernizacją mostu stalowego na linii kolejowej nr 408, Szczecin-Berlin.

Słowa kluczowe: mosty stalowe, stal zlewna, spawalność stali

\section{Abstract}

After a period of use of a building changes the ability to meet the full range of designed functions, above all, its durability and usable technology. This problem applies to railway bridges. Over $75 \%$ of these structures has more than 50 years, of which nearly $45 \%$ are operated for over 100 years, so already exceeded the assumed working life. These objects are strengthened and modernized. This fact requires prior knowledge of the current characteristics of material-strength steel construction and weldability.

In the paper this is shown selected aspects of the modernization of the railway steel bridge No. 408, the line Szczecin-Berlin.

Keywords: steel bridges, confluent steel, weldability

\section{Wstęp}

W ramach Regionalnego Programu Operacyjnego województwa zachodniopomorskiego na lata 2002-2013 przeprowadzono modernizację dwóch regionalnych linii kolejowych i kilku mostów [1, 2]. Jednym z tych mostów jest konstrukcja usytuowana na linii nr 408 Szczecin-Stobno-Granica RP-Berlin, której remont wykonano na przełomie 2012/2013 roku. Według danych z karty ewidencyjnej obiekt został odbudowany w 1948 r. z konstrukcji poniemieckiego pochodzenia i nieznanego miejsca wcześniejszej eksploatacji. Pierwotnie była to kolejowa linia dwutorowa i mosty usytuowane w omawianym kilometrze zostały zniszczone w wyniku działań wojennych w końcu II wojny światowej.

Obecnie do Berlina, oddalonego od Szczecina w linii kolejowej $110 \mathrm{~km}$, podróż pociągiem trwa 2 godziny. Ponieważ do Berlina nie mogą wjeżdżać

Dr hab. inż. Bernard Wichtowski, em. prof. ZUT, dr inż. Ryszard Pakos - Zachodniopomorski Uniwersytet Technologiczny w Szczecinie. 
lokomotywy spalinowe, w Angermünde następuje zmiana lokomotywy lub pasażerowie przesiadają się do elektrycznego składu. $\mathrm{Na}$ linii tej brakuje zaledwie $33 \mathrm{~km}$ elektryfikacji, w tym $10 \mathrm{~km}$ torów po stronie polskiej i $23 \mathrm{~km}$ po stronie niemieckiej. Według informacji w „Głosie Szczecińskim”, z 19.11.2012 r., Komisja Rejonu Gartz nad Odra już w czerwcu 2009 r. podjęła uchwałę o pilnej konieczności rozbudowy dwutorowej trasy, jej zelektryfikowania i przystosowania do prędkości 160 km/h. Porozumienie pomiędzy Polską i Niemcami w zakresie modernizacji linii zostało zawarte dopiero w ostatnich dniach grudnia 2012 r. Według doniesień prasowych szczególne zainteresowanie budową tej linii wykazuje Berlin Brandenburg Airport. Samoloty berlińskich lotnisk rocznie przewożą ok. $1 \mathrm{mln}$ pasażerów z Pomorza Zachodniego, którzy docierają tam głównie samochodami.

Uznano, że kolej jest dobrym uzupełnieniem komunikacyjnym dla tego rejonu.

\section{Konstrukcja mostu}

Widok mostu przedstawiono na rysunku 1, a jego dane ewidencyjno-konstrukcyjne obrazują rysunki 2 i 5. Most wykonano jako typową, jednoprzęsłową, nitowaną, stalową konstrukcję blachownicową z jazdą górą. Prawdopodobnie wybudowana została na po-

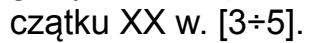

Rozpiętość podporowa przęsła wynosi 26,40 m. Długość dźwigarów nośnych jest równa 27,00 m, przy czym ich osiowy rozstaw poprzeczny wynosi $1,75 \mathrm{~m}$, a szerokość poprzeczna łącznie $\mathrm{z}$ dwustronnymi chodnikami 4,40 m. Dźwigary blachownicowe wykonano ze środnika o przekroju poprzecznym $18 \times 2100$ mm oraz z pasów o różnej grubości i jednakowej szerokości $450 \mathrm{~mm}$ na całej ich długości. Pas górny w strefie podporowej ma grubość $16 \mathrm{~mm}$, a pas dolny $18 \mathrm{~mm}$ i są one na swej rozpiętości, w części środkowej, wzmocnione dwoma nakładkami. Poszczególne pasy ze środnikiem są połączone przez nitowanie dwoma kątownikami równoramiennymi 180x180x16 mm (rys. 2).

Sztywność przestrzenną mostu zapewniają stężenia pionowe poprzeczne oraz poziome w płaszczyźnie pasa górnego i dolnego (rys. 6a). Stężenie wiatrowe w poziomie pasów górnych wykonstruowane jest ze słupków z kątownika 110×110x10 mm w odstępach co 1,76 m oraz krzyżulców z kątowników 90x90x10 mm. Stężenie pionowe w odstępach co 3,52 m wykonane jest w przęśle jako krzyżowe, a na podporze jako $\mathrm{V} z$ pojedynczych kątowników 90x90x10 mm (rys. 2b i 6a). W osi stężeń pionowych założone są także kątownikowe rozpórki w poziomie pasa dolnego.
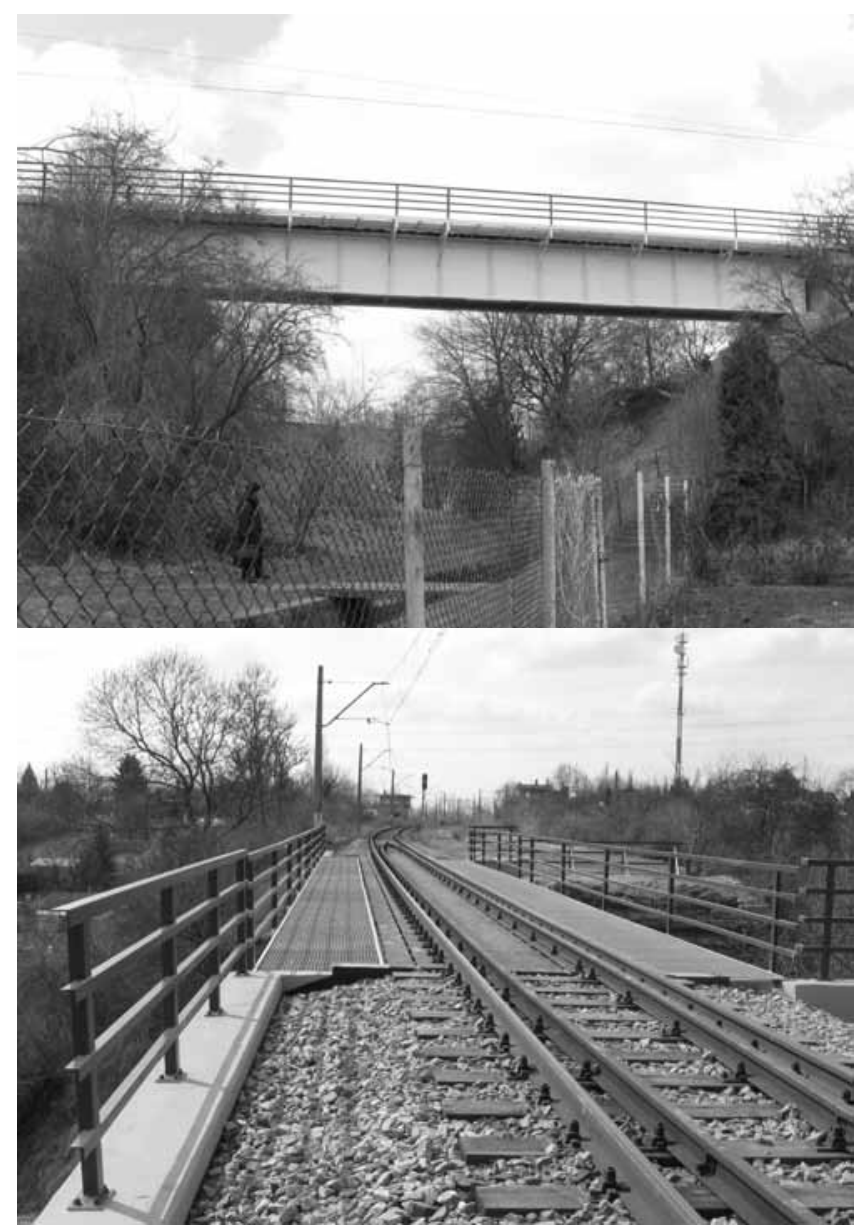

Rys. 1. Widok ogólny mostu i jego nawierzchnia po remoncie

Fig. 1. View of bridge and the railway after modernization

a)

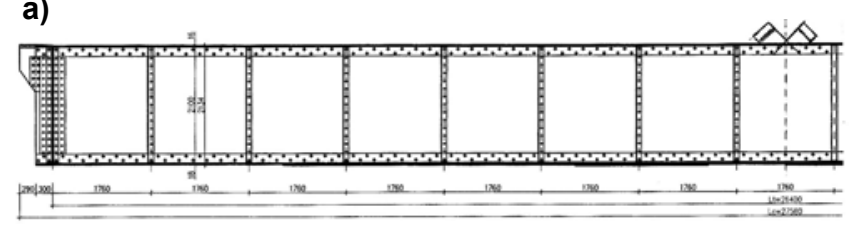

b)

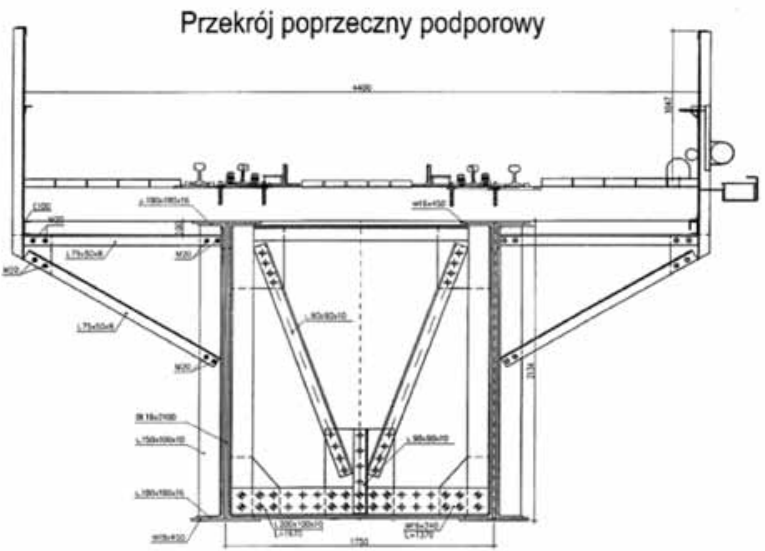

Rys. 2. Konstrukcja mostu: a) widok boczny dźwigara głównego, b) przekrój poprzeczny

Fig. 2. Bridge structure: a) side view of the main beam, b) crosssection 


\section{Skład chemiczny i właściwości mechaniczne stali}

Ze strefy podporowej jednego $z$ dźwigarów blachownicowych wycięto odcinek stali środnika, z której wykonano próbki do badań materiałowych. Charakterystykę składu chemicznego wypolerowanej powierzchni próbki wykonano spektrometrem emisyjnym jarzeniowym GDS 500A firmy LECO. Analizę przeprowadzono dla trzech wypaleń na próbce, a jej wyniki zawarto w tablicy I. Zamieszczono $w$ niej średnie arytmetyczne procentowe zawartości podstawowych 9 pierwiastków, z 21 pierwiastków zbadanych. Jednocześnie $w$ tablicy tej, w celach porównawczych, podano skład chemiczny węglowej stali zlewnej (Flußstahl) oraz jej odmiany o podwyższonej wytrzymałości oznaczonej symbolem St52 (Hochwertige Baustahle). Stale te stosowali Niemcy w konstrukcjach budowlanych do lat czterdziestych XX w.

Dane stali zlewnej określono wg [2, 6], natomiast stal St52 była produkowana w różnych odmianach, przy dość zróżnicowanym składzie dodatków stopowych [7, 8]. Państwowe Koleje w Niemczech dopiero w 1937 r. wydały wytyczne dla tej stali, określające jej skład chemiczny i cechy wytrzymałościowe [9]. W tablicy I podano dane aktualnego zamiennika stali St52, jakim jest wg DIN 17102-83 stal niskostopowa o podwyższonej wytrzymałości StE355, oraz do niedawna stosowanej w polskim mostownictwie stali St3M wg PN$-89 / \mathrm{H}-84023 / 04$ i stali $18 \mathrm{G} 2 \mathrm{wg} \mathrm{PN}-86 / \mathrm{H}-84018$. Zgodnie $z$ zaleceniami normy mostowej PN-82/S-10052, stal $18 G 2$ stosujemy na elementy $w$ konstrukcjach nitowanych z jednoczesnym przyjęciem jej wytrzymałości obciążeniowej o $10 \mathrm{MPa}$ niższej od wykazanej.

Z porównania składu chemicznego poszczególnych gatunków stali wynika, że konstrukcja mostu została wykonana ze stali St52 o właściwościach obecnej stali niemieckiej StE355. Na uwage w jej składzie zasługuje znaczna zawartość: manganu, krzemu i chromu, a ich odchyłka standardowa $w$ badaniach wyniosła odpowiednio $1,10 \% ; 2,22 \%$ i $6,49 \%$. Jednocześnie zawartości siarki $(0,0158 \%)$ i fosforu $(0,0221 \%)$ nie przekraczają ilości, które aktualnie uznaje się za dopuszczalne, tj. 0,040\%.
Właściwości mechaniczne i plastyczne stali z konstrukcji mostu określono na podstawie badań statycznego rozciągania próbek okrągłych, pięciokrotnych o średnicy bazowej $10 \mathrm{~mm}$. Z uwagi na małą szerokość wyciętego odcinka stali ze środnika dźwigara mostu, próbki wykonano $z$ blachy o kierunku prostopadłym do kierunku jej walcowania; są to tzw. próbki poprzeczne. Z literatury wynika, że próbki poprzeczne przy badaniach udarnościowych mają mniejszą wartość pracy łamania. Analogiczne właściwości stwierdził autor (BW) przy badaniach stali z blachownicowych dźwigarów pod suwnice półbramownicowe w [10]. Cechy tej nie stwierdzono jednak w przypadku próbek o zróżnicowanych kierunkach ich pobrania, przy badaniach statycznego rozciągania. Przy określonej wartości $R_{\mathrm{e}}$ różnica wyniosła $1,4 \%$, a przy wyznaczaniu $R_{m}$ jedynie $0,7 \%$. Przyjęto, że różnice te stanowią błąd pomiaru.

Zbadano trzy próbki o parametrach podanych na rysunku 3, który przedstawia wykres ich rozciągania. Badania prowadzono zgodnie z PN-EN ISO 6892:2010 na maszynie wytrzymałościowej Zwick/Roell Z600, a ich wyniki podano $w$ tablicy II. Wartości charakterystyczne właściwości mechanicznych stali wynoszą:

- minimalna wartość górnej granicy plastyczności:

$\mathrm{R}_{\mathrm{eH}}=370 \mathrm{MPa}$,

- granica wytrzymałości na rozciąganie:

$\mathrm{R}_{\mathrm{m}}=590 \mathrm{MPa}$,

- procentowe wydłużenie stali:

$A_{5}=23 \%$.

Przyjmując wartość $\mathrm{R}_{\mathrm{e}}=\min \mathrm{R}_{\mathrm{eH}}=371 \mathrm{MPa}$ oraz „mostowy" współczynnik materiałowy $Y_{s}=1,20+0,05=1,25$, otrzymuje się przy grubości elementów $\mathrm{t} \leq 16 \mathrm{~mm}$ :

- wytrzymałość charakterystyczną:

$\mathrm{f}_{\mathrm{yk}}=370>355 \mathrm{MPa}$,

- wytrzymałość obliczeniową

$\mathrm{f}_{\mathrm{d}}=370 / 1,25=295-10=285 \mathrm{MPa}$.

Wykorzystując próbkę do badań składu chemicznego, określono twardość stali, którą mierzono w tzw. warunkach standardowych, używając kulki stalowej o średnicy $D=10 \mathrm{~mm}$ przy obciążeniu $P=29430 \mathrm{~N}$ utrzymywanym przez czas $t=15 \mathrm{~s}$. Badania przeprowadzono twardościomierzem B3 CS, a ich wyniki zamieszczono w tablicy II.

Tablica I. Skład chemiczny stali, z której wykonano most, oraz stali starych i współczesnych Table I. Chemical composition of bridge steel and the old and current used steels

\begin{tabular}{|c|c|c|c|c|c|c|c|c|c|}
\hline \multirow{2}{*}{$\begin{array}{l}\text { Rodzaj } \\
\text { stali }\end{array}$} & \multicolumn{9}{|c|}{ Skład chemiczny stali, \% wag. } \\
\hline & $\mathrm{C}$ & $\mathrm{Mn}$ & $\mathrm{Si}$ & $P$ & $S$ & $\mathrm{Cu}$ & $\mathrm{Cr}$ & $\mathrm{Ni}$ & $\mathrm{Al}$ \\
\hline $\begin{array}{c}\text { Stal } \\
\text { badana }\end{array}$ & 0,196 & 1,250 & 0,378 & 0,0221 & 0,0158 & 0,0634 & 0,223 & 0,0008 & 0,0016 \\
\hline $\begin{array}{c}\text { Stal } \\
\text { zlewna }\end{array}$ & $\begin{array}{c}0,030 \\
\div 0,350\end{array}$ & $\begin{array}{c}0,040 \\
\div 0,750\end{array}$ & $\begin{array}{c}\text { ślady } \\
\div 0,180\end{array}$ & $\begin{array}{c}0,004 \\
\div 0,160\end{array}$ & $\begin{array}{c}0,004 \\
\div 0,115\end{array}$ & $\begin{array}{c}0,110 \\
\div 0,140\end{array}$ & $\begin{array}{c}0,007 \\
\div 0,014\end{array}$ & $\begin{array}{c}0,030 \\
\div 0,040\end{array}$ & $\begin{array}{c}0,010 \\
\div 0,020\end{array}$ \\
\hline $\begin{array}{c}\text { StE355 } \\
\text { (St52) }\end{array}$ & $\begin{array}{l}\max \\
0,200\end{array}$ & $\begin{array}{c}0,900 \\
\div 1,650\end{array}$ & $\begin{array}{c}0,100 \\
\div 0,500\end{array}$ & $\begin{array}{c}\max \\
0,035\end{array}$ & $\begin{array}{c}\max \\
0,030\end{array}$ & $\begin{array}{c}\max \\
0,200\end{array}$ & $\begin{array}{l}\max \\
0,300\end{array}$ & $\begin{array}{c}\max \\
0,300\end{array}$ & $\begin{array}{c}\min \\
0,020\end{array}$ \\
\hline St3M & $\max 0,200$ & $\min _{0,040}$ & $\begin{array}{c}0,120 \\
\div 0,300\end{array}$ & $\begin{array}{c}\max \\
0,050\end{array}$ & $\begin{array}{c}\max \\
0,050\end{array}$ & - & $\begin{array}{l}\max \\
0,300\end{array}$ & $\begin{array}{l}\max \\
0,300\end{array}$ & $\begin{array}{l}\max \\
0,300\end{array}$ \\
\hline $18 \mathrm{G} 2$ & $\max 0,200$ & $\begin{array}{c}1,000 \\
\div 1,5000\end{array}$ & $\begin{array}{c}0,200 \\
\div 0,350\end{array}$ & $\begin{array}{l}\max \\
0,040\end{array}$ & $\begin{array}{l}\max \\
0,040\end{array}$ & $\begin{array}{c}\max \\
0,300\end{array}$ & $\begin{array}{l}\max \\
0,300\end{array}$ & $\begin{array}{l}\max \\
0,300\end{array}$ & $\min 0,020$ \\
\hline
\end{tabular}


Ocenę zachowania się stali $\mathrm{z}$ konstrukcji mostu w wypadku wystąpienia warunków sprzyjających kruchym pękaniom przeprowadzono na podstawie próby udarności. Badania wykonano na próbkach Charpy'ego (KCV) w czterech zakresach temperatury, od -40 do $+20^{\circ} \mathrm{C}$, przy ich zróżnicowaniu co $20^{\circ} \mathrm{C}$. Uzyskane wyniki przedstawiono w tablicy III i na rysunku 4.

Na rysunku 4, oprócz przedstawienia wartości średniej udarności na danym poziomie temperaturowym, zaznaczono poziomą linię, określającą udarność na poziomie $34 \mathrm{~J} / \mathrm{cm}^{2}$. Jest to minimalna wartość krytyczna udarności KCV stawiana przez Eurokod 3 stalom nowych konstrukcji w przypadku badania próbek O $A=80 \mathrm{~mm}^{2}$. W PN-EN 1993-1-10:2007 podano, że „praca łamania $A_{v}(T) w$ dżulach [J], potrzebna do złamania próbki udarnościowej z karbem ostrym Charpy $\vee$ w określonej temperaturze badania $T$ była nie niższa niż 27 J." Oznacza to dla badanych próbek wartość

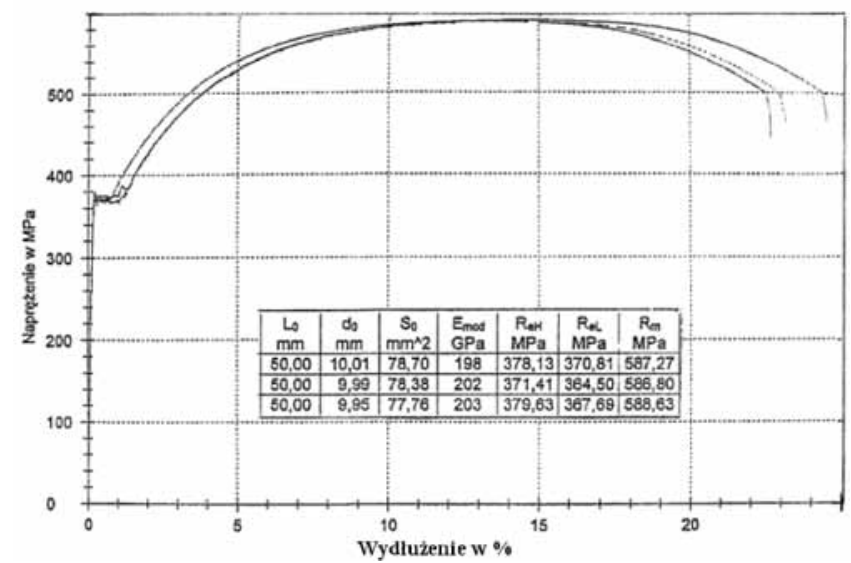

Rys. 3. Wykres rozciągania próbek ze stali środnika dźwigara głównego Fig. 3. The scheme of tensile strength of the web of main beam

Tablica II. Właściwości mechaniczne stali badanej i stali porównawczych Table II. Mechanical properties of tested and compared steels udarności $\mathrm{KCV}=34 \mathrm{~J} / \mathrm{cm}^{2}$. Analogiczną wartość $\mathrm{K}_{\mathrm{v}}$ dla próbek wzdłużnych ze stali S355 w stanie JR, JO i J2, w temperaturze $20^{\circ} \mathrm{C} \mathrm{i}-20^{\circ} \mathrm{C}$ podano $\mathrm{w}$ normie hutniczej PN-EN 10025-2, natomiast dla stali mostowej S355 w stanie N, NL, M i ML wartość $K_{v}$ jest większa $(27 \div 63 \mathrm{~J})$ i przyjmowana wg PN-EN 10025-3 oraz PNEN 10025-4.

Określone wyżej wymagania udarnościowe dotyczą nowych konstrukcji stalowych. Wskazane w tablicy III wartości udarności pozwalają na oszacowanie plastyczność stali mostu oraz określenie stopnia jej zestarzenia. Badana stal wykazała stosunkowo mała udarność w temperaturze ujemnej. Uzyskana udarność KCV $=20,2 \mathrm{~J} / \mathrm{cm}^{2} \mathrm{w}$ temperaturze $-20^{\circ} \mathrm{C}$ stanowi $59,4 \%$ wymaganej udarności normatywnej $\left(34 \mathrm{~J} / \mathrm{cm}^{2}\right)$. Temperatura przejścia badanej stali w stan kruchy wynosi $-8,5^{\circ} \mathrm{C}$ (rys. 4), a tzw. wskaźnik starzenia wg [10] ma wartość $W_{s}=20,2 / 34=0,59$.

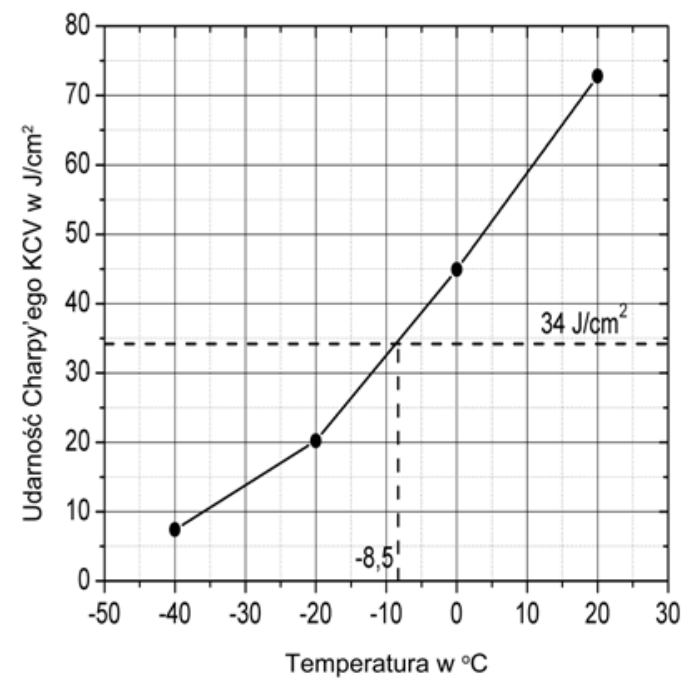

Rys. 4. Średnia udarność próbek ze stali środnika dźwigara mostu Fig. 4. The average impact strength of the web of main beam

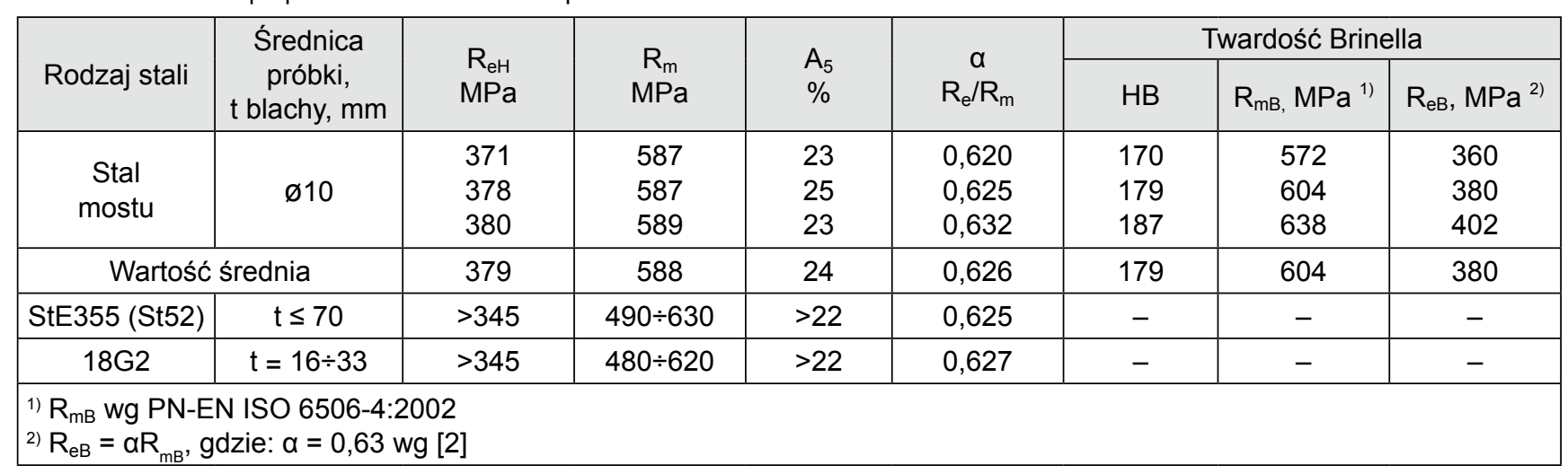

Tablica III. Udarność próbek Charpy'ego

Table III. Impact strength in Charpy's test

\begin{tabular}{|c|c|c|c|c|c|c|c|c|}
\hline \multirow{2}{*}{ Element } & \multicolumn{3}{|c|}{ Wymiary próbki } & \multirow{2}{*}{$\begin{array}{l}\text { Numer } \\
\text { próbki }\end{array}$} & \multicolumn{4}{|c|}{ Udarność KCV w J/cm² } \\
\hline & przekrój, mm & karb, $\mathrm{mm}$ & pole, $\mathrm{mm}^{2}$ & & $-40^{\circ} \mathrm{C}$ & $-20^{\circ} \mathrm{C}$ & $0^{\circ} \mathrm{C}$ & $20^{\circ} \mathrm{C}$ \\
\hline $\begin{array}{c}\text { Stal } \\
\text { środnika } \\
\text { dźwigara }\end{array}$ & $10 \times 10$ & 2 & 80 & $\begin{array}{l}1 \\
2 \\
3\end{array}$ & $\begin{array}{l}7,4 \\
7,4 \\
7,4\end{array}$ & $\begin{array}{l}16,1 \\
20,0 \\
24,6\end{array}$ & $\begin{array}{l}40,7 \\
45,0 \\
49,1\end{array}$ & $\begin{array}{l}72,4 \\
72,5 \\
73,6\end{array}$ \\
\hline \multicolumn{5}{|c|}{ Wartość średnia } & 7,4 & 20,2 & 44,9 & 72,8 \\
\hline
\end{tabular}




\section{Ocena spawalności stali}

Podczas remontu mostu przewidziano oparcie mostownic na pasach górnych dźwigarów blachownicowych w sposób pokazany na rysunku 5. Bezpośrednie przekazywanie obciążenia z mostownic na most jest dokonywane przez podkładki centrujące oznaczone 1. Zamontowane 94 podkładki o zmiennej wysokości wzdłuż obiektu (h od 50 do $\sim 90 \mathrm{~mm}$ ) są bezpośrednio spawane do pasów górnych w osi środnika. Takie rozwiązanie konstrukcyjne likwiduje poprzeczne zginanie blachy pasa dźwigara pod mostownica [3] (rys. 6b). Podkładki te o długości $210 \mathrm{~mm}$ i szerokości $40 \mathrm{~mm}$ zespawane są spoinami pachwinowymi grubości a $=4 \mathrm{~mm}$, co warunkuje konieczność wykonania oceny spawalności stali mostu.

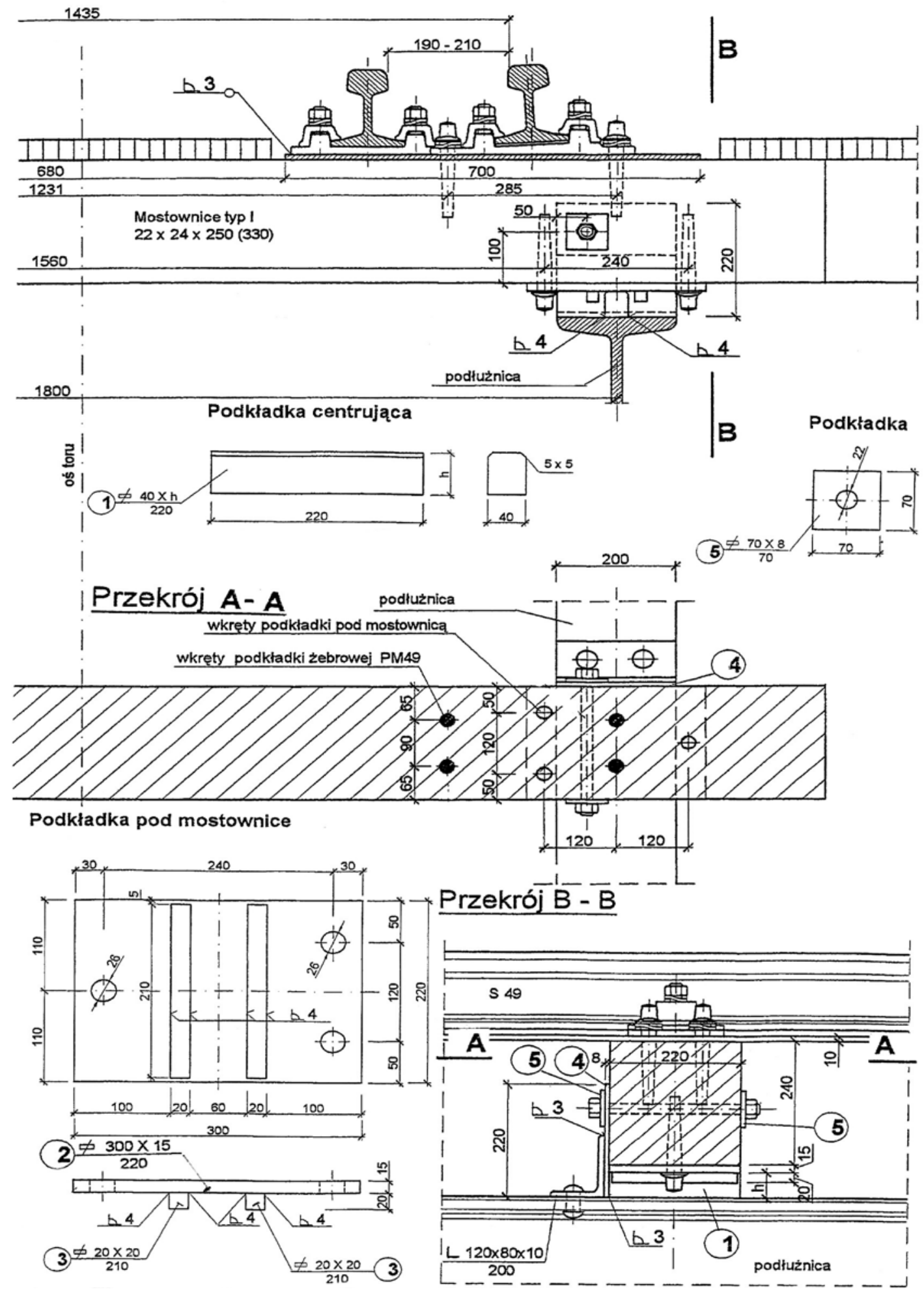

Rys. 5. Projektowane oparcie mostownicy na pasie górnym dźwigara

Fig. 5. Designed support of bridge sleeper of the main beam 


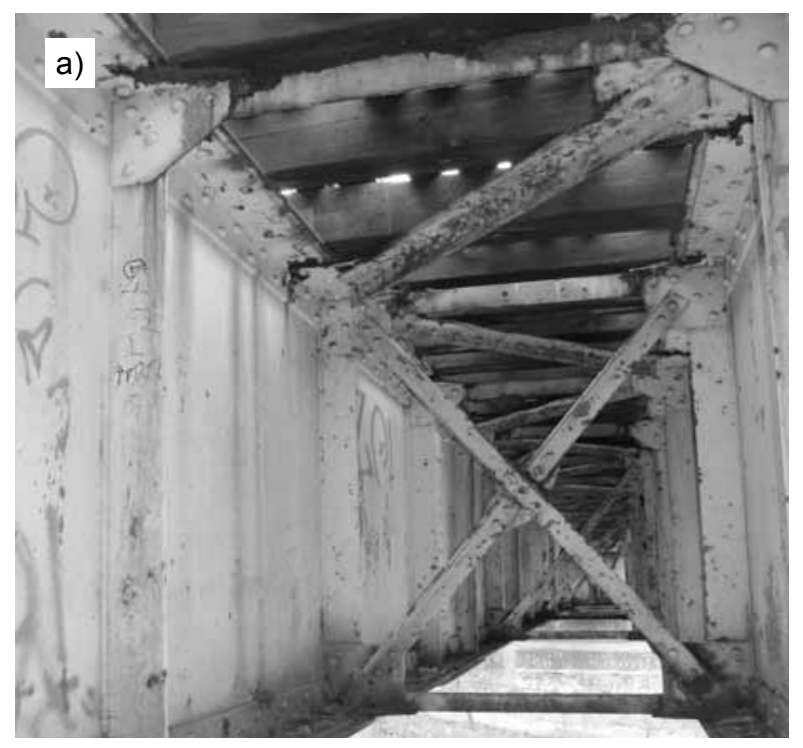

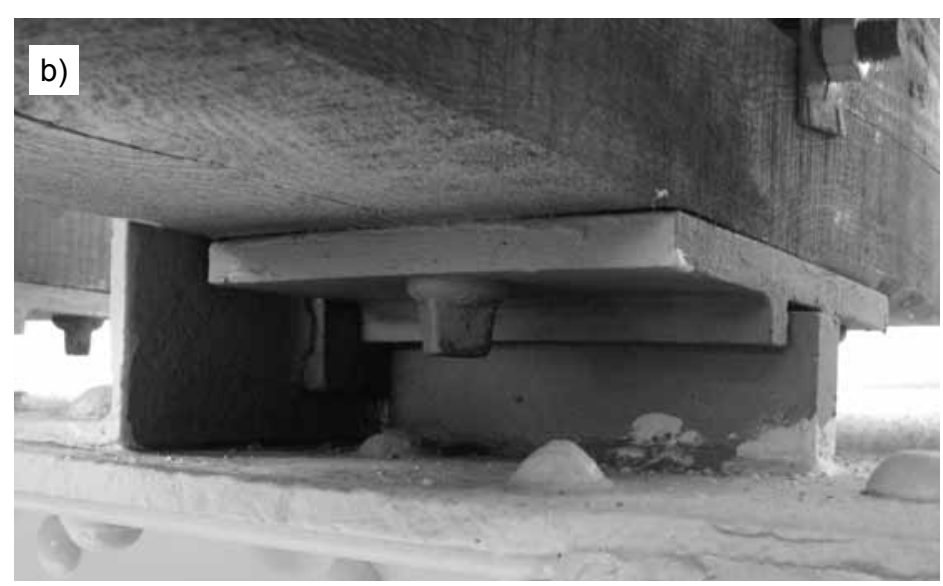

Rys. 6. Oparcie mostownic: a) bezpośrednio na pasach górnych dźwigarów (przed remontem), b) na płytkach centrujących (po remoncie)

Fig. 6. Support of bridge sleeper: a) direct on the main beam (before modernization), b) on the centre plates (after modernization)
W odniesieniu do modernizowanego mostu autorzy określili spawalność metalurgiczną, oszacowaną na podstawie składu chemicznego według obliczonych poniższych wskaźników $(1 \div 7)$ przyjętych z [11 $\div 13]$ :

- równoważnik węgla

$\mathrm{C}_{\mathrm{e}}=\mathrm{C}+\frac{\mathrm{Mn}}{6}+\frac{\mathrm{Cr}+\mathrm{Mo}+\mathrm{V}}{5}+\frac{\mathrm{Ni}+\mathrm{Cu}}{15}=0,454 \%>0,43 \%$

- wskaźnik odporności na pękanie

$\mathrm{HCS}=1000\left(\mathrm{~S}+\mathrm{P}+\frac{\mathrm{Si}}{25}+\frac{\mathrm{Ni}}{100}\right) \frac{\mathrm{C}}{3 \mathrm{Mn}+\mathrm{Cr}+\mathrm{Mo}+\mathrm{V}}=2,61 \%<4 \%$

$\mathrm{C}_{\text {ekw }}=\mathrm{C}+2 \mathrm{~S}+\frac{\mathrm{P}}{3}+\frac{\mathrm{S}-0,4}{10}+\frac{\mathrm{Mn}-0,8}{12}+\frac{\mathrm{Ni}}{12}+\frac{\mathrm{Cu}}{15}+\frac{\mathrm{Cr}-0,8}{15}=0,236 \%>0,15 \%$

- wskaźnik oceny skłonności do pękania zimnego, gdzie: $\mathrm{t}=16 \mathrm{~mm}$

$C^{\prime}=C+\frac{M n}{6}+\frac{P}{2}+\frac{M o}{4}+\frac{N i}{15}+\frac{C u}{13}+\frac{C r+V}{5}+0,0024 t=0,504 \%>0,4 \%$

- twardość strefy wpływu ciepła

$\mathrm{HV}_{\max }=90+1050 \mathrm{C}+47 \mathrm{Si}+75 \mathrm{Mn}+30 \mathrm{Ni}+31 \mathrm{Cr}=414 \mathrm{HV}>350 \mathrm{HV}$

$\mathrm{HV}_{\max }=1200 \mathrm{C}_{\mathrm{e}}-200=405 \mathrm{HV}>350 \mathrm{HV}$

$\mathrm{HV}_{\text {min }}=1200 \mathrm{C}_{\mathrm{e}}^{\prime}-260=345 \mathrm{HV}<350 \mathrm{HV}$ a)

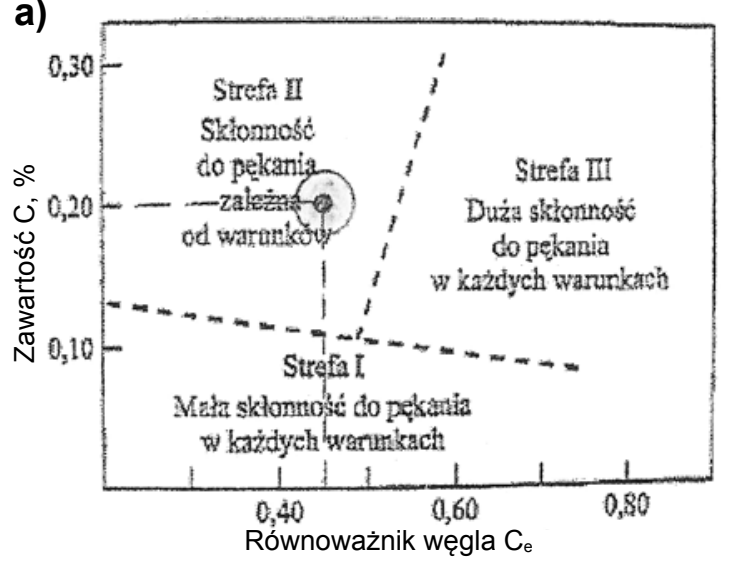

Z wyjątkiem wskaźników (2) i (7) obliczone wartości pozostałych wskaźników są większe od wartości skrajnych, granicznych. Stal, z której wykonano most, jest skłonna do powstawania pęknięć i jest spawalna warunkowo (rys. 7). Dla aktualnie zalecanej stali mostowej S355N i S355NL, o właściwościach stali St52 w omawianym moście, wg PN -EN 10025-3 (dla elementów o grubości $\leq 63 \mathrm{~mm}$ ) wartość $\mathrm{C}_{e}$ nie powinna przekraczać $0,43 \%$.

Rys. 7. Parametry stali: a) wpływ zawartości $C$ i $C_{e}$ na podatność pęknięć w SWC, b) zależność spawalności od $C_{e}$ i grubości blachy pasa górnego [7, 13]

Fig. 7. Steel properties: a) influence of the $C$ and $C_{e}$ content on cracks susceptibility in HAZ, b) function of weldability and the upper beam plate thickness 


\section{Wnioski}

Z uzyskanych wyników badań i wyliczonych wskaźników spawalności wynika, że:

- most został wykonany z niskostopowej stali zlewnej St52 o właściwościach do niedawna stosowanej stali niemieckiej StE355 wg DIN 17102-83,

- stal jest stalą uspokojoną, gdyż Si $=0,378 \%>$ $0,12 \%$, o strukturze drobnoziarnistej i P $=0,022 \%$ $<0,05, \%$

- wytrzymałość charakterystyczna stali $\mathrm{f}_{\mathrm{yk}}=\mathrm{R}_{\mathrm{emin}}$ $=370 \mathrm{MPa}$,

- wytrzymałość obliczeniowa stali $\mathrm{f}_{\mathrm{d}}=285 \mathrm{MPa}$ dla $\mathrm{t} \leq 16 \mathrm{~mm}$,

- stal jest spawalna warunkowo, ma tendencje do powstawania pęknięć na zimno z powodu hartowania się SWC,

- uzyskano dużą zgodność wartości $R_{m}$ i $R_{e}$ otrzymanych ze statycznego rozciągania stali i badań twardości $\mathrm{HB}$; różnice wynoszą jedynie $+2,7 \%$ i $+3,3 \%$
Spawanie płytek centrujących pod mostownice (rys. 5 i 6) należy prowadzić z zachowaniem poniższych zaleceń:

- podkładki centrujące spawać spoinami pachwinowymi o grubości a $=4 \mathrm{~mm}$,

- przed spawaniem w miejscu podkładki odcinek pasa górnego dźwigara blachowniczego długości $400 \mathrm{~mm}$ podgrzać do temperatury $200^{\circ} \mathrm{C}$,

- podgrzewać palnikiem z użyciem propanu-butanu w celu wyeliminowania ewentualnego nawęglenia stali pasów przy podgrzewaniu z użyciem acetylenu,

- do spawania używać elektrod zasadowych niskowodorowych, np. OK.55.00, wg EN499 oznaczonych jako E46 5B 32 oraz wg ISO 2560 jako E515 B $12026 \mathrm{H}$.

\section{Literatura}

[1] Wichtowski B., Hołowaty J.: Ocena właściwości stali mostów na modernizowanych regionalnych liniach kolejowych woj. zachodniopomorskiego. Mosty, nr 2/2012.

[2] Wichtowski B., Hołowaty J.: Analiza właściwości materiałowych i spawalniczych stali zlewnej mostów kolejowych. Inżynieria i Budownictwo, nr 5/2013.

[3] Madaj A., Wołowicki W.: Budowa i utrzymanie mostów. WKŁ, Warszawa 1995.

[4] Bień J.: Uszkodzenia i diagnostyka obiektów mostowych. WKŁ, Warszawa 2010.

[5] Wiśniewski D., Majka M., Bień J.: Ocena nośności mostów w okresie ich eksploatacji. Doświadczenia krajowe i zagraniczne. Inżynieria i Budownictwo, nr 7-8/2013.

[6] Madaj A., Skarżewski J.: Ocena właściwości stali zgrzewanych i wczesnych stali zlewnych w konstrukcjach mostowych. Inżynieria i Budownictwo, nr 2/1986.

[7] Czapliński K.: Dawne wyroby ze stopów żelaza. Dolnośląskie Wydawnictwo Edukacyjne, Wrocław 2009.

[8] Hołowaty J.M., Wichtowski B.: Properties of Structural Steel used in Earlier Railway Bridges. Structural Engineering International, 4/2013.

[9] Stahlbau-Kalender. Verlag von Wilhelm Ernst und Sohn, Berlin 1940.

[10] Wichtowski B., Hołowaty J.: Badania udarnościowe stali zlewnej mostów kolejowych. Inżynieria i Budownictwo, nr $1 / 2014$.

[11] Tasak E.: Spawalność stali. Fotobit, Kraków 2002.

[12] Rykaluk K., Wichtowski B.: Wytrzymałość konstrukcji mostowej z pęknięciami w spawanych złączach czołowych. Materiały XLIII Konferencji Naukowej KILiW PAN i KN PZITB, tom V, Poznań-Krynica 1997.

[13] Blicharski M.: Inżynieria materiałowa. Stal. WNT, Warszawa 2004.

\section{Przegląd Spawalnictwa Welding Technology Review Open Access Library}

Przegląd Spawalnictwa uruchomił możliwość wolnego dostępu do pełnych treści artykułów w ramach Open Access Library. Artykuły w języku angielskim w formacie PDF zamieszczane są na tronie internetowej redakcji: www.pspaw.ps.pl.

Autorów zainteresowanych publikacją w Open Access Library prosimy o przesyłanie artykułów w języku polskim i angielskim. W miesięczniku nastąpi publikacja w języku polskim, a tekst w języku angielskim zostanie zamieszczony na stronie internetowej. 